KALAMATIKA Jurnal Pendidikan Matematika

Volume 3, No. 1, April 2018, hal. 27-38

$\mathbf{K} \backslash \mathbf{L} \backslash \mathbf{M} / \mathbf{T} \backslash \mathbf{K} /$

\title{
PROSES BERPIKIR SISWA YANG MENGALAMI MATH-ANXIETY DALAM MENYELESAIKAN MASALAH SISTEM PERSAMAAN LINIER DUA VARIABEL
}

\author{
Muhammad Irfan \\ Universitas Sarjanawiyata Tamansiswa \\ muhammad.irfan@ustjogja.ac.id
}

\begin{abstract}
ABSTRAK
Aljabar merupakan salah satu materi yang sulit dipahami oleh siswa, khususnya yang mengalami math-anxiety. Penelitian ini bertujuan untuk mendeskripsikan: (1) proses berpikir siswa yang memiliki math-anxiety tinggi dalam memecahkan masalah matematika sesuai langkah-langkah Polya, (2) proses berpikir siswa yang memiliki math-anxiety rendah dalam memecahkan masalah matematika sesuai langkah-langkah Polya. Jenis Penelitian ini adalah penelitian kualitatif dengan metode studi kasus. Pengambilan sampel dilakukan dengan teknik purposive sampling. Subjek yang digunakan dalam penelitian ini sebanyak dua subjek penelitian, yaitu: siswa yang memiliki math-anxiety tinggi, siswa yang memiliki math-anxiety rendah. Instrumen yang digunakan untuk mengumpulkan data adalah penggolongan tingkat kecemasan belajar matematika, lembar tugas memecahkan masalah matematika, dan pedoman wawancara. Uji validasi data yang digunakan adalah uji triangulasi waktu. Pada penelitian ini, peneliti menggunakan tipe berpikir reflektif dan kreatif untuk menganalisa proses berpikir subyek. Hasil penelitian menunjukkan: (1) pada saat memahami masalah, merencanakan pemecahan masalah, menjalankan rencana pemecahan masalah, dan memeriksa kembali jawaban, siswa yang mengalami math-anxiety tinggi menggunakan proses berpikir reflektif, (2) pada saat memahami masalah dan memeriksa kembali jawaban, siswa yang mengalami math-anxiety rendah menggunakan proses berpikir reflektif, sedangkan pada saat merencanakan pemecahan masalah dan menjalankan rencana pemecahan masalah, subjek melakukan proses berpikir reflektif dan kreatif.
\end{abstract}

Kata kunci: math-anxiety, proses berpikir, sistem persamaan linier dua variabel

\begin{abstract}
Algebra is one of the most difficult material for students to understand, especially those experiencing math-anxiety. This study aimed to describe: (1) the thinking process of students who have high math-anxiety in solving mathematical problems according to Polya steps, (2) the thinking process of students who have low math-anxiety in solving mathematical problems according to Polya steps. Type this research is qualitative research with case study method. Sampling is done by purposive sampling technique. Subjects used in this study as much as two research subjects, namely: students who have high anxiety math, students who have low anxiety math. The instruments used to collect data are classification of anxiety level of mathematics learning, mathematics problem sheet, and interview guidance. The data validation test used is the triangulation test of time. In this study, researchers used a type of reflective and creative thinking to analyze the thinking process of the subject. The results show: (1) when understanding the problem, planning problem solving, running problem-solving plan, and re-examining answers, students experiencing high math-anxiety using reflective thinking process, (2) when
\end{abstract}


understanding the problem and re-examining answers, students who experience low anxiety math using reflective thinking processes, while at the time of planning problem solving and running problem-solving plans, the subject engages in a process of reflective and creative thinking.

Keywords: math-anxiety, thinking process, linear equation with two variables

Format Sitasi: Irfan, M. (2018). Proses Berpikir Siswa yang Mengalami Math-Anxiety dalam Menyelesaikan Masalah Sistem Persamaan Linier Dua Variabel. KALAMATIKA Jurnal Pendidikan Matematika, 3(1), 27-38.

Penyerahan Naskah: 24 April 2017 || Revisi: 19 Maret 2018 || Diterima: 22 Maret 2018

\section{PENDAHULUAN}

Kecemasan dalam belajar dapat menyebabkan kesulitan belajar. Kecemasan belajar matematika (math-anxiety) sering dialami oleh siswa baik saat belajar di dalam kelas ataupun di luar kelas. Saat math-anxiety meningkat, maka prestasi dan performa matematika siswa mengalami penurunan (Lee, 2009; Beilock \& Maloney, 2015). Menurut Beilock dan Maloney (2015), jika siswa mengalami math-anxiety, maka kemampuan matematikanya pun lemah serta dia akan menghindar dari situasi matematika. Menurut Freedman (2012), math-anxiety dapat dikelompokkan menjadi empat kelompok, yaitu: siswa memiliki math-anxiety tinggi, memiliki math-anxiety agak tinggi, memiliki math-anxiety sedang (rata-rata), dan memiliki math-anxiety rendah. Siswa yang memilki math-anxiety berakibat terhadap kurangnya pemahaman konsep. Akibatnya, saat siswa dihadapkan pada permasalahan, ia cenderung mengalami kesulitan dalam menyelesaikannya (Irfan, 2017).

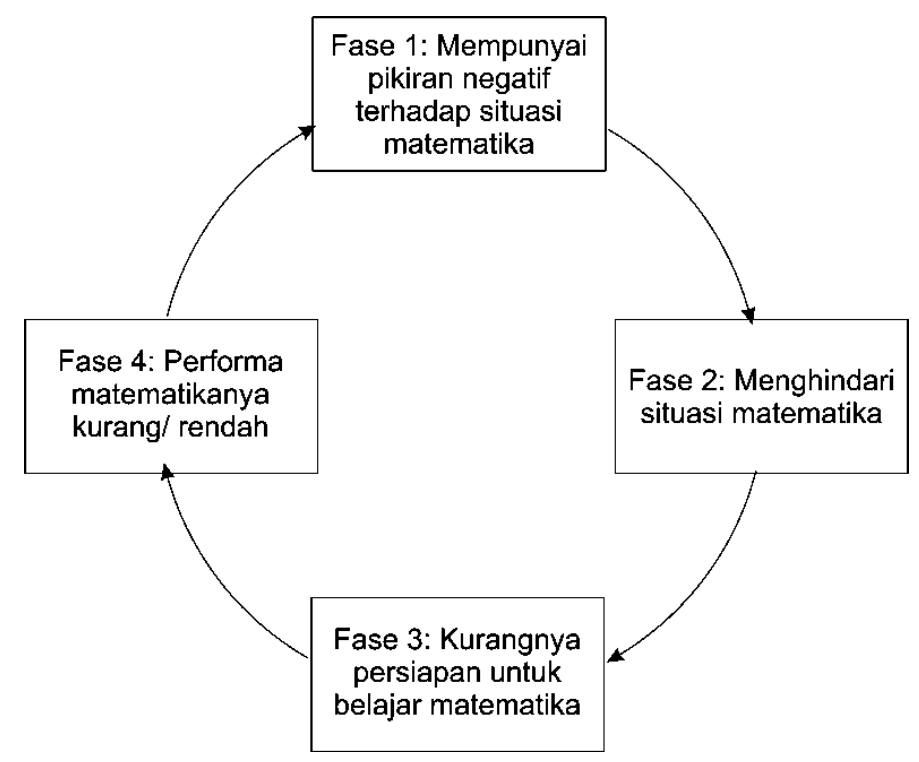

Gambar 1. Lingkaran Math-anxiety 
Math-anxiety dapat terjadi pada saat siswa memiliki pikiran negatif terhadap pembelajaran matematika atau apa pun yang berhubungan dengan matematika. Saat siswa mempunyai pikiran negatif, selanjutnya ia akan cenderung untuk menghindar dari situasi yang berhubungan dengan matematika. Saat matematika sudah tidak menarik bagi siswa, ia tidak akan terlalu banyak persiapan dan tidak akan banyak belajar tentang matematika. Akibatnya, performa/ capaian kinerjanya pun kurang (lihat Gambar 1).

Salah satu materi yang dianggap sulit dipahami oleh siswa adalah aljabar. Konsep variabel, koefisien, pemfaktoran, menggambar grafik, dan akar-akar merupakan bagian yang paling sulit dipahami oleh siswa (Tim LRN, 2004). Pada tingkat pendidikan SMP kelas VIII, materi aljabar yang dipelajari salah satunya adalah sistem persamaan linier dua variabel. Pada materi sistem persamaan linier dua variabel, siswa memerlukan pemahaman yang mendalam untuk menyelesaikan masalah. Masalah sistem persamaan linier dua variabel, siswa harus dapat memahami masalah yang diberikan, merubah pemahaman ke dalam bentuk model matematika, merencanakan penyelesaian dan kemudian menjalankan rencana. Setelah didapatkan hasil, siswa perlu melihat kembali pekerjaan yang telah dilakukan. Tahapan-tahapan tersebut merupakan langkah-langkah penyelesaian masalah berdasarkan Polya (1978).

Berpikir merupakan proses dinamis, dalam hal ini subjek bersifat aktif dalam memecahkan berbagai masalah yang bersifat abstrak. Pada penelitian ini, proses berpikir yang digunakan adalah proses berpikir reflektif dan kreatif. Menurut Choy dan Oo (2012) menyebutkan bahwa berpikir reflektif berdasarkan pada empat karakteristik: (a) refleksi sebagai analisis retrospektif, (b) refleksi sebagai pemecahan masalah, (c) refleksi kritis terhadap diri sendiri, dan (d) refleksi keyakinan tentang diri dan self-efficacy. Menurut Dewey (Phan, 2008), berpikir reflektif adalah aktif secara simultan, gigih, dan mempertimbangkan dengan cermat mengenai sesuatu hal yang dipercaya kebenarannya. Seseorang yang berpikir reflektif, cenderung untuk menanyakan kembali kepada dirinya sendiri mengenai informasi yang didapatnya, tidak secara utuh menerima dengan apa adanya (Phan, 2006). Menurut Nindiasari (2013), berpikir reflektif memuat kemampuan untuk menginterpretasikan, mengaitkan pengetahuan yang dimiliki, dan mengevaluasi setiap langkah yang ditempuh.

Dalam penelitian ini, yang dimaksud dengan berpikir reflektif adalah kemampuan mengidentifikasi masalah, membatasi dan merumuskan masalah, mengajukan beberapa kemungkinan alternatif solusi pemecahan masalah, mengumpulkan data yang dibutuhkan untuk 
memecahkan masalah, dan melakukan tes untuk menguji solusi pemecahan masalah serta menggunakannya sebagai bahan pertimbangan membuat kesimpulan dalam suatu masalah matematika.

Berpikir kreatif merupakan salah satu perwujudan dari berpikir tingkat tinggi. Berpikir kreatif merupakan aktivitas mental untuk membuat koneksi secara simultan sehingga ditemukan kombinasi yang benar atau sampai individu tersebut menyerah. Berpikir kreatif tidak berdasarkan pada pemikiran logis tetapi lebih sebagai pemikiran yang tiba-tiba muncul, tak terduga, dan di luar kebiasaan (Gatot, 2012: 316). Evans (Yuli, 2009) mengemukakan bahwa berpikir kreatif merupakan aktivitas mental untuk membuat koneksi secara terus menerus. Sehingga, ditemukan kombinasi yang "benar" atau sampai seseorang itu menyerah. Jadi, hubungan (pola) yang dibentuk itu didasarkan pada informasi-informasi yang ada serta pengalaman belajar yang dimiliki melalui pemikiran secara analogis sampai diperoleh ide-ide baru yang berbeda dengan ide-ide sebelumnya. Jadi dapat dikatakan bahwa, seseorang yang berpikir kreatif, cenderung mengabaikan aturan-aturan yang sudah mapan, dan menciptakan aturan-aturan tersendiri. Seseorang yang berpikir kreatif, ia akan berpikir yang tak pernah diduga oleh orang lain. Pengertian ini menunjukkan bahwa berpikir kreatif merupakan kegiatan mental untuk menemukan suatu kombinasi yang belum dikenal sebelumnya.

Berpikir kreatif dapat pula dipandang sebagai proses seseorang untuk memunculkan ide baru. Ide baru tersebut dapat berupa gabungan dari ide-ide yang telah ada, yang belum pernah diwujudkan (Infinite Innovation Ltd, 2001; Yudi, Ariani \& Ramadianti, 2017). Pengertian ini lebih memfokuskan pada proses seseorang untuk memunculkan gagasan baru yang merupakan gabungan gagasan-gagasan sebelumnya yang belum diwujudkan atau masih dalam pemikiran. Pengertian berpikir kreatif ini ditandai dengan adanya gagasan baru yang dimunculkan sebagai suatu hasil dari proses berpikir. Apapun yang dilakukan, dengan membuat sesuatu yang baru, ataupun menambah sentuhan baru terhadap sesuatu yang sudah ada maka kreativitas telah muncul tanpa kita sadari (Rochyani, 2004). Dari beberapa pendapat di atas, dapat disimpulkan bahwa proses berpikir kreatif merupakan suatu aktivitas mental yang digunakan seorang untuk membangun, menghasilkan ide atau gagasan yang baru.

Berdasarkan penjelasan sebelumnya, penelitian ini bertujuan untuk mendeskripsikan bagaimana proses berpikir siswa yang mengalami math-anxiety tinggi dan siswa yang mengalami math-anxiety rendah dalam menyelesaikan masalah sistem persamaan linier dua 
variabel. Harapannya, paparan pada penelitian ini dapat dimanfaatkan untuk menyusun strategi dan memilih metode pembelajaran agar siswa yang mengalami math-anxiety mampu memahami materi dengan baik. Salah satu indikator siswa paham materi dengan baik adalah mampu menyelesaikan masalah yang diberikan.

\section{METODE PENELITIAN}

Penelitian ini menggunakan jenis penelitian kualitatif dengan metode studi kasus. Metode yang digunakan dalam penelitian ini adalah studi kasus dimana peneliti berusaha untuk mengetahui bagaimana proses berpikir siswa pada saat memecahkan masalah matematika di SMP Negeri 2 Ngaglik, D. I. Yogyakarta. Subjek penelitian dipilih berdasarkan teknik purposive sampling. Peneliti mendapatkan subjek penelitian atas saran dari guru mata pelajaran dan hasil pengisian instrumen math-anxiety yang berasal dari kelas VIII A, B, C, dan D. Pada mulanya, siswa diberikan kuesioner math-anxiety. Kuesioner test math-anxiety diadobsi dari Freedman (2012), yang terdiri dari 10 pertanyaan. Setelah itu, peneliti mengelompokkan ke dalam 4 kelompok, yaitu: math-anxiety tinggi, math-anxiety agak tinggi, math-anxiety sedang, dan math-anxiety rendah. Kemudian, peneliti memilih kelompok math-anxiety rendah dan tinggi untuk diberikan instrumen soal. Instumen soal pada penelitian ini dapat dilihat pada Tabel 1.

Tabel 1. Instrumen soal

\begin{tabular}{lc}
\hline \multicolumn{1}{c}{ Soal } & Keterangan \\
\hline $\begin{array}{l}\text { Luas sebuah area parkir adalah } 300 \mathrm{~m}^{2} \text {. Sebuah bus memerlukan lahan parkir } \\
\text { seluas } 24 \mathrm{~m}^{2} \text { dan mobil } 6 \mathrm{~m}^{2} \text {. Jika banyaknya mobil yang dapat diparkir } \\
\text { adalah } 10 \text { buah lebih banyak dari banyaknya bus, berapakah paling banyak } \\
\text { bus dan mobil yang dapat ditampung area parkir tersebut? }\end{array}$ & Soal Tes \\
$\begin{array}{l}\text { Selisih dua bilangan adalah 10. Jika bilangan pertama dikalikan dua hasilnya } \\
\text { adalah tiga kurangnya dari bilangan yang kedua. Berapakah kedua bilangan } \\
\text { tersebut? }\end{array}$ & Soal Triangulasi \\
\hline
\end{tabular}

Dalam penelitian ini, uji validasi data yang digunakan adalah uji triangulasi waktu. Proses analisis data pada penelitian ini berdasarkan dari pekerjaan subyek dan wawancara dengan subyek.

\section{HASIL DAN PEMBAHASAN}

\section{Siswa yang Memiliki Math-anxiety Tinggi (MT)}

Berikut adalah hasil pekerjaan Subjek MT. 


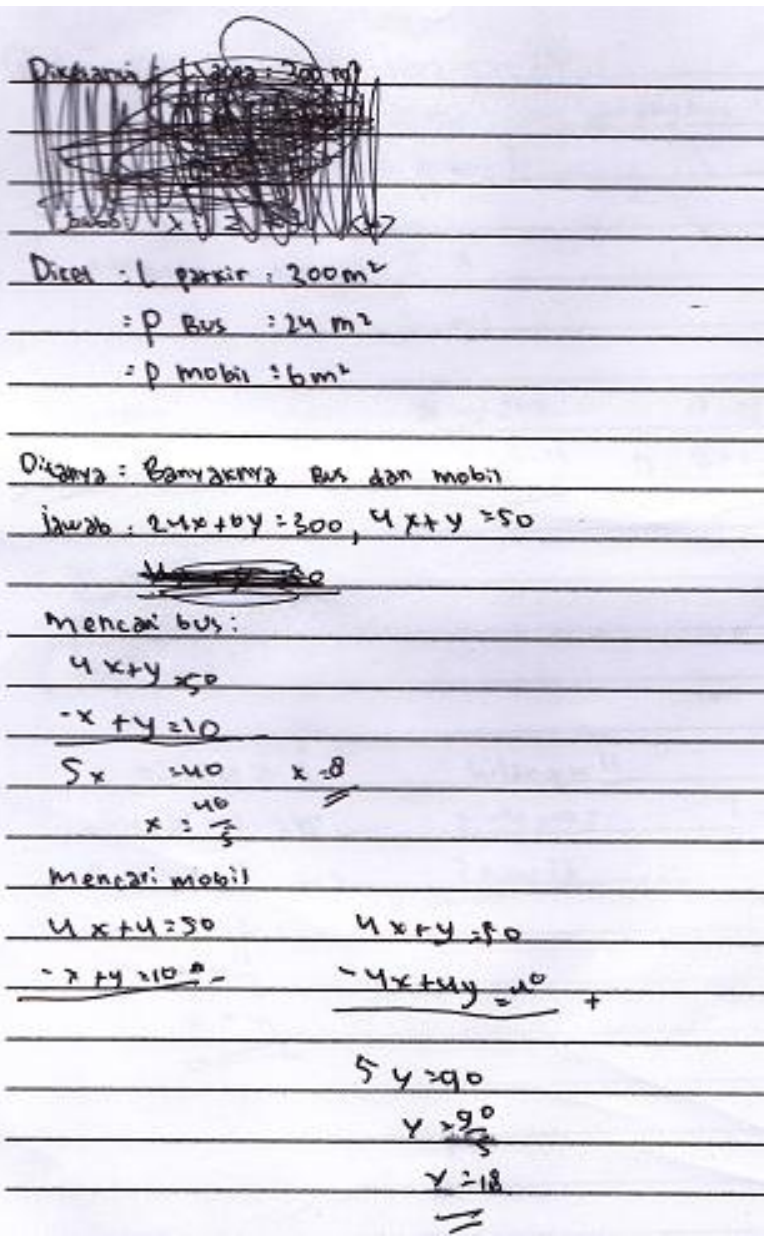

Gambar 1. Pekerjaan Subjek MT

Pada saat memahami masalah, subjek dapat mengidentifikasi apa yang diketahui dan yang ditanyakan dari masalah dengan benar. Namun Subyek sempat ragu dengan apa yang dituliskannya. Saat peneliti bertanya, "mengapa bagian ini kamu coret-coret (sambil menunjuk bagian yang dicoret)?”. Subyek menjawab, ”salah pak.”, “dari mana kamu tahu kalau salah?”, peneliti bertanya lagi. “[diam lama]”. Kemudian peneliti bertanya,"setelah kamu menyadari bahwa ada kesalahan, lalu kamu ganti dengan menuliskan ini (sambal menunjuk bagian bawah coretan)?”. Subyek menjawab,"iya pak". Berdasarkan wawancara tersebut, Subjek dapat memahami proses berpikirnya sendiri. Hal ini terlihat pada saat subjek menjawab pertanyaan peneliti. Subjek dapat menyeleksi ilmu pengetahuannya yang digunakan untuk memahami masalah. Dari uraian tersebut, dapat disimpulkan bahwa siswa mengalami math-anxiety tinggi menggunakan proses berpikir reflektif dalam memahami masalah.

Pada saat merencanakan pemecahan masalah, subjek mula-mula mengubah kalimat matematika menjadi bentuk model matematika. Kemudian, ia memperoleh dua persamaan dan 
dibentuklah sistem persamaan linier dua variabel. Selain itu, subjek dapat menuliskan dengan benar persamaan tersebut dan dapat menjelaskan terkait persamaan yang telah dibuatnya. Setelah didapatkan sistem persamaan linier dua variabel, subjek merencanakan pemecahan masalah tersebut dengan menggunakan metode eliminasi. Subjek dapat menyeleksi ilmu pengetahuannya yang digunakan untuk merencanakan pemecahan masalah. Subjek dapat memahami proses berpikirnya sendiri. Hal ini tampak pada saat subjek menjawab pertanyaan peneliti. Berdasarkan uraian tersebut, dapat disimpulkan bahwa subjek melakukan proses berpikir reflektif pada saat merencanakan pemecahan masalah.

Pada saat memecahkan masalah, subjek menggunakan persamaan yang telah dibuat pada langkah sebelumnya. Selanjutnya, siswa menggunakan metode eliminasi untuk memecahkan masalah tersebut. Hal ini berarti, siswa mampu memecahkan masalah sesuai dengan yang telah direncanakan. Subjek dapat memahami setiap langkah yang ia tulis dan menjawab pertanyaan wawancara dengan baik. Subjek mampu menerapkan strategi pemecahan masalah yang telah disusun dengan baik dan memahami setiap langkah yang ia tuliskan. Subjek menggunakan ilmu pengetahuan yang ia miliki untuk digunakan memecahkan masalah. Sehingga dapat dikatakan bahwa subjek melakukan proses berpikir reflektif pada saat menjalankan rencana pemecahan masalah.

Subjek dapat memeriksa kembali jawaban yang telah diperoleh dari tahap memahami masalah hingga menjalankan perencanaan pemecahan. Subjek dapat menentukan cara untuk memeriksa hasil yang didapat yaitu dengan cara mensubstitusikan hasil yang diperoleh ke salah satu persamaan. Subjek memahami setiap langkah yang ia tuliskan. Subjek dapat memberikan alasan yang logis terkait pemilihan cara memeriksa kembali jawaban. Subjek juga mampu menyeleksi ilmu pengetahuan yang diperolehnya yang kemudian digunakan untuk memeriksa jawaban. Jadi, dapat dikatakan bahwa siswa yang mengalami math-anxiety tinggi melakukan proses berpikir reflektif dalam memeriksa kembali jawaban.

\section{Siswa yang Memiliki Math-anxiety Rendah (MR)}

Berikut adalah hasil pekerjaan subjek MR 


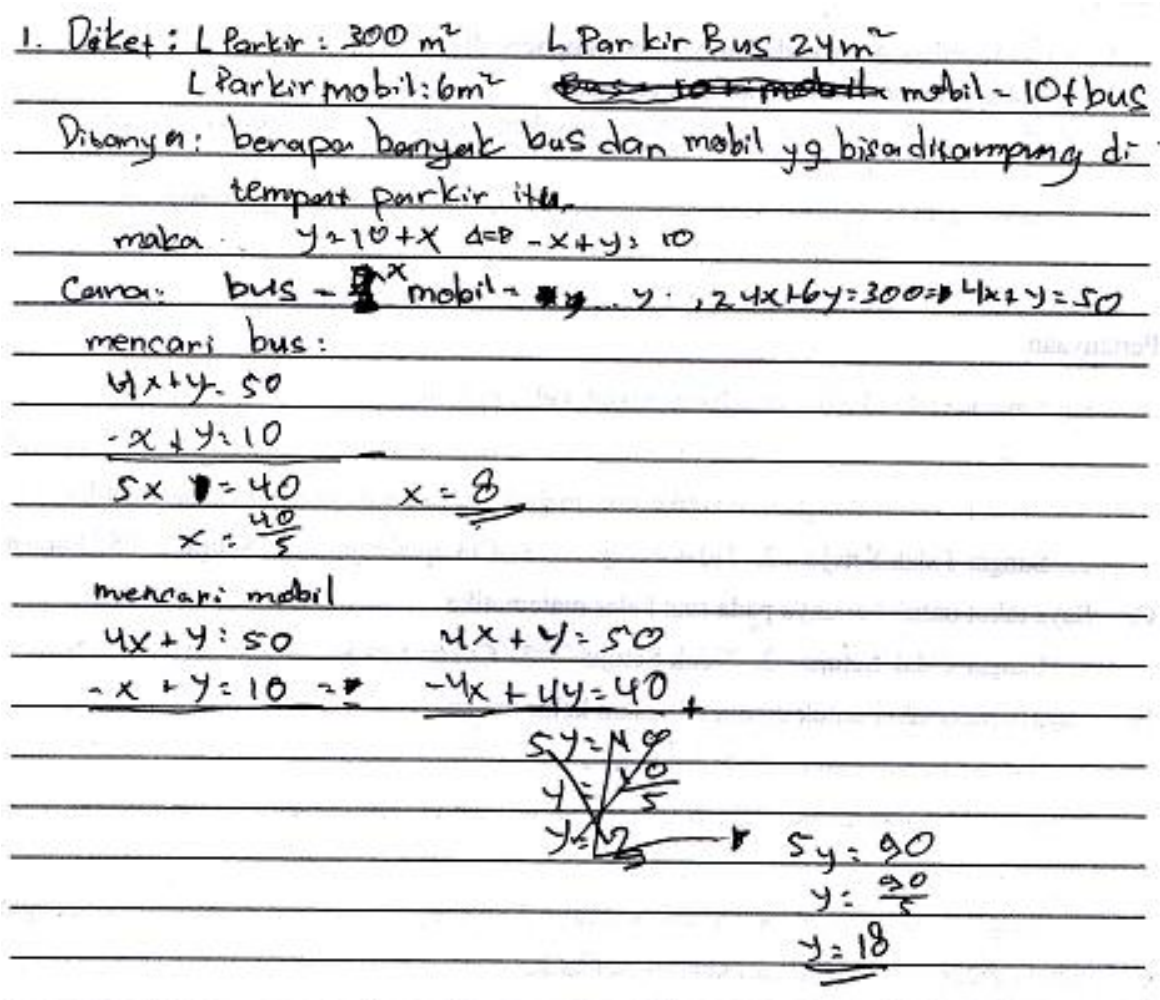

$\therefore$ baryaknyer mobil 18 buah dan banyarknya bus 8

Gambar 2. Pekerjaan Subjek MR dengan cara 1

$\begin{array}{cc}y & =x+10 \\ 4 x+y=50 & 4(87+y=50 \\ 4 x+(x+10)=50 & 32+y=50 \\ 4 x+x+10=50 & y=50-32 \\ 5 x=40 & y=18 \\ x=\frac{410}{5} & \\ x & =8\end{array}$

Gambar 3. Pekerjaan Subjek MR dengan cara 2

Pada saat subjek memahami masalah, subjek dapat dapat mengidentifikasi berbagai informasi penting dari masalah yang diberikan. Subjek dapat memilih ilmu pengetahuannya (recall) yang digunakan untuk memahami masalah. Subjek dapat memberikan alasan setiap kalimat yang ditulis. Hal ini nampak pada saat subjek menjawab pertanyaan peneliti. Oleh karena itu, dapat dikatakan bahwa siswa yang mengalami math-anxiety rendah melakukan proses berpikir reflektif pada saat memahami masalah. 
Pada saat merencanakan pemecahan masalah, subjek terlebih dahulu mengubah kalimat matematika ke dalam bentuk model matematika. Setelah itu, subjek memperoleh sistem persamaan linier dua variabel. Subjek juga mampu menuliskan dengan benar persamaan tersebut dan dapat menjelaskan mengenai persamaan yang telah dibuatnya. Setelah didapatkan sistem persamaan linier dua variabel, subjek merencanakan pemecahan masalah dengan menggunakan metode eliminasi. Subjek dapat memilih ilmu pengetahuan yang dimilikinya dan digunakan untuk merencanakan pemecahan masalah. Subjek dapat memberikan alasan dari setiap tulisan pada pekerjaannya. Hal ini tampak pada saat subjek menjawab pertanyaan peneliti. Subjek juga dapat merencanakan pemecahan masalah dengan menggunakan metode yang lain. Dengan kata lain, subjek mempunyai banyak alternatif cara untuk memecahkan masalah. Sehingga dapat dikatakan bahwa siswa yang mengalami math-anxiety rendah menggunakan proses berpikir reflektif dan kreatif dalam merencanakan pemecahan masalah.

Pada saat memecahkan masalah, subjek memanfaatkan persamaan-persamaan yang telah dibuat pada langkah sebelumnya. Subjek kemudian menggunakan metode eliminasi untuk memecahkan masalah. Berarti, siswa dapat memecahkan masalah sesuai dengan perencanaan yang telah dibuat. Selain itu, subjek mampu memberikan alternatif cara penyelesaian yang dapat digunakan untuk memecahkan masalah. Subjek memahami setiap langkah yang ia tuliskan dan menjawab pertanyaan wawancara dengan baik. Subjek mampu menerapkan strategi pemecahan masalah yang telah disusun dengan baik dan paham di setiap langkah yang ia lakukan. Subjek menggunakan ilmu pengetahuan yang ia miliki yang kemudian digunakan untuk memecahkan masalah. Selain itu, subjek juga dapat memikirkan alternatif cara lain yang dapat digunakan untuk memecahkan masalah. Subjek dapat menemukan solusi dengan menggunakan cara yang berbeda, sehingga dapat dikatakan subjek melakukan proses berpikir reflektif dan kreatif pada saat menjalankan rencana pemecahan masalah. Berikut kutipan wawancara dengan Subyek

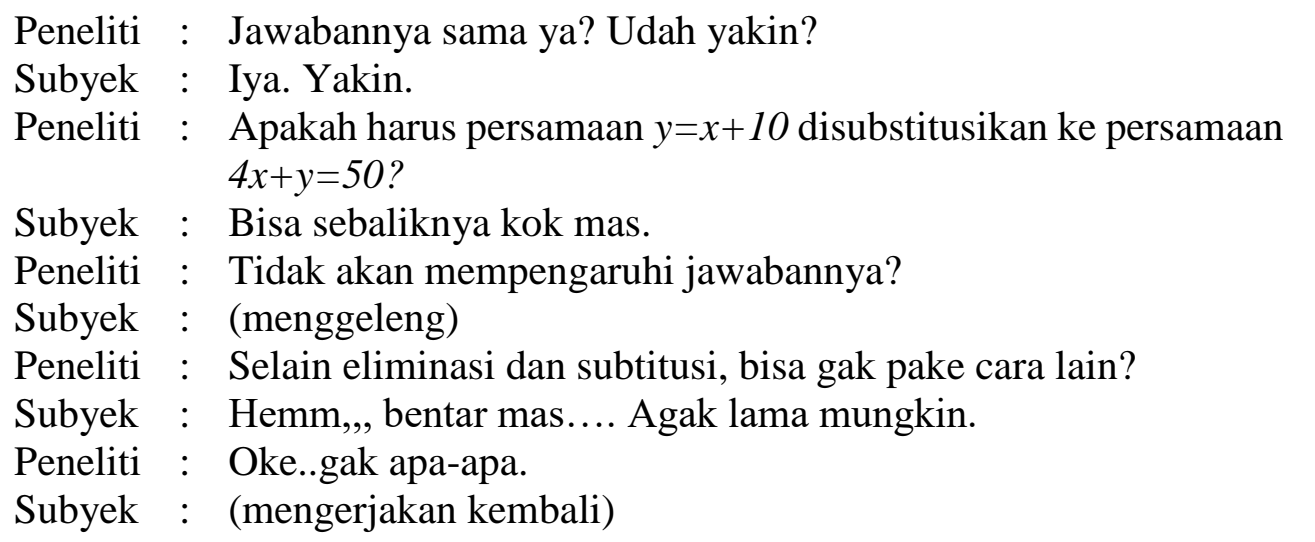




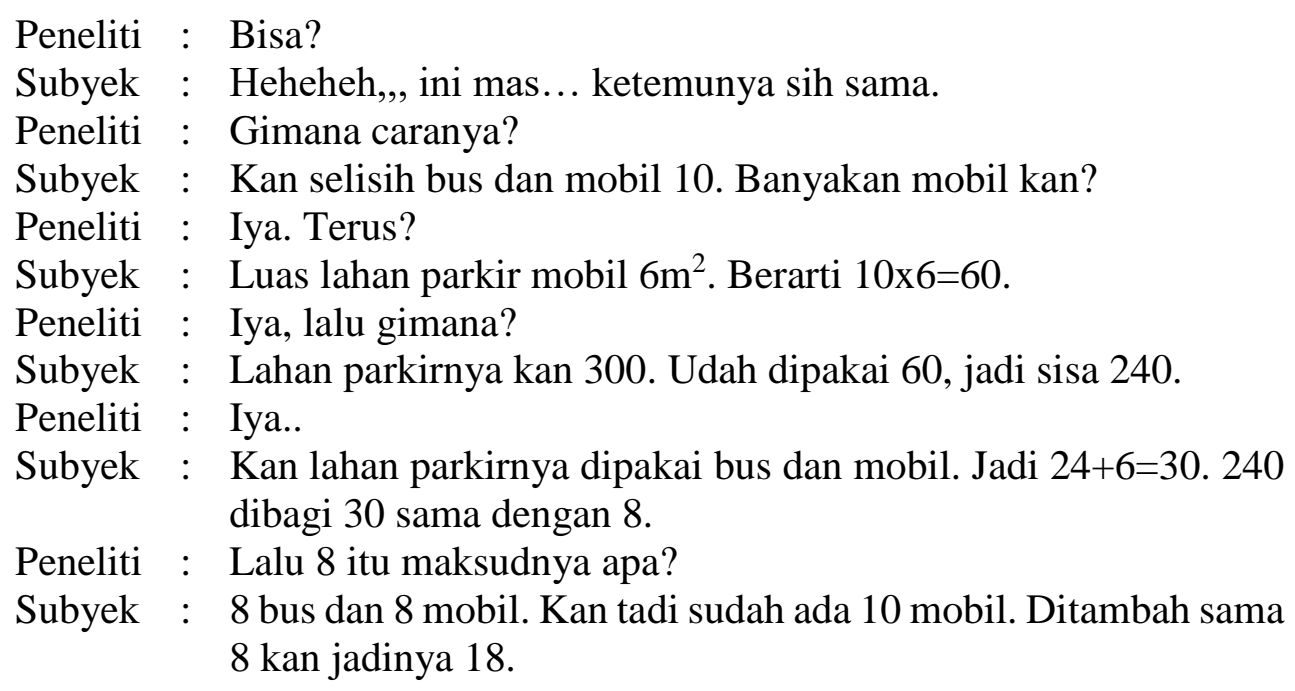

Subjek dapat memeriksa kembali jawaban yang telah diperoleh dari tahap memahami masalah hingga menjalankan perencanaan pemecahan masalah. Subjek dapat menentukan cara untuk memeriksa hasil yang didapat yaitu dengan cara mensubstitusikan hasil yang diperoleh ke salah satu persamaan. Subjek mampu memahami setiap langkah yang ia kerjakan. Subjek dapat mengemukakan alasan yang logis terkait pemilihan cara memeriksa kembali jawaban. Subjek yakin dalam menjawab pertanyaan dari peneliti. Subjek juga dapat menyeleksi ilmu pengetahuan yang diperolehnya. Pengetahuan itug kemudian digunakan untuk memeriksa jawaban. Oleh karena itu, dapat dikatakan bahwa subjek melakukan proses berpikir reflektif dalam memeriksa kembali jawaban.

\section{KESIMPULAN}

Berdasarkan analisis dan pembahasan sebelumnya, dapat disimpulkan sebagai berikut: (1) pada saat memahami masalah, merencanakan pemecahan masalah, menjalankan rencana pemecahan masalah, dan memeriksa kembali jawaban, siswa yang mengalami math-anxiety tinggi menggunakan proses berpikir reflektif, (2) pada saat memahami masalah dan memeriksa kembali jawaban, siswa yang mengalami math-anxiety rendah menggunakan proses berpikir reflektif, sedangkan pada saat merencanakan pemecahan masalah dan menjalankan rencana pemecahan masalah, subjek melakukan proses berpikir reflektif dan kreatif.

\section{REKOMENDASI}

Penelitian ini masih perlu dikembangkan dengan penelitian-penelitian selanjutnya. Penelitian yang dapat diteliti selanjutnya adalah mengenai perilaku siswa yang mengalami 
kecemasan belajar matematika pada saat menyelesaikan masalah dan pada saat pembelajaran berlangsung. Selain itu, dapat pula dikembangkan lembar kegiatan siswa, model pembelajaran, atau pemanfaatan teknologi untuk mereduksi kecemasan belajar matematika seperti penelitian yang dilakukan oleh Irfan (2015).

\section{REFERENSI}

Beilock, S. L., \& Maloney, E. A. (2015). Math-anxiety: A factor in math achievement not to be ignored. Policy Insights from the Behavioral and Brain Sciences, 2(1), 4-12.

Choy, S. C., \& Oo, P. S. (2012). Reflective Thinking and Teaching Practices: A Precursor for Incorporating Critical Thinking into the Classroom? Online Submission, 5(1), 167182.

Freedman, E. (2012). Anxtest. [Online]. Tersedia: http://www.mathpower.com/anxtest.htm [5 Maret 2012]

Gatot, F. I. M. (2012). Menumbuhkan Kemampuan Berpikir Kreatif pada Siswa Sekolah Dasar Melalui pembelajaran Matematika Berbasis Masalah. Prosiding Seminar Nasional Pendidikan Matematika Universitas Negeri Yogyakarta. Hal: 314 - 321

Infinite Innovation. Ltd. (2001). Tutorial on Creativity, Brainstorming and Innovation. (Online), (http://www.brainstorming.co.uk/tutorialscontents.html.), diakses 2 Februari 2010.

Irfan, M. (2017). Analisis Kesalahan Siswa dalam Pemecahan Masalah Berdasarkan Kecemasan Belajar Matematika. Kreano, Jurnal Matematika Kreatif-Inovatif, 8(2).

Irfan, M. (2015). Pemanfaatan Gadget dalam Pembelajaran Matematika serta Pengaruhnya Pada Mahasiswa yang Mengalami Math-anxiety di Universitas Sarjanawiyata Taman Siswa Pada Mata Kuliah Persamaan Differensial. SCIENCE TECH: Jurnal Ilmiah Ilmu Pengetahuan dan Teknologi, 1(1), 68-76.

Lee, J. (2009). Universals and specifics of math self-concept, math self-efficacy, and mathanxiety across 41 PISA 2003 participating countries. Learning and individual differences, 19(3), 355-365.

Nindiasari, H. (2013). Meningkatkan kemampuan dan disposisi berpikir reflektif matematis serta kemandirian belajar siswa sma melalui pembelajaran dengan pendekatan metakognitif (Doctoral disertation, Universitas Pendidikan Indonesia).

Phan, H. P. (2006). Examination of student learning approaches, reflective thinking, and epistemological beliefs: A latent variables approach. 4(3), 577-610. 
Phan, H. P. (2008). Achievement goals, the classroom environment, and reflective thinking: A conceptual framework. Electronic Journal of Research in Educational Psychology, 6(3), 571-602.

Polya, G. (1978). How to Solve It: A New Aspect of Mathematical Method second edition. New Jersey: Princeton University Press.

Rochyani, I. (2004). Meningkatkan Kreativitas Siswa SMA Melalui Pembelajaran Matematika Berbasis Masalah pada Pokok Bahasan Program Linier. UPI Bandung: tidak diterbitkan.

Tim LRN. (2004). 1001 Math Problems. New York: Learning Express.

Yuli, T. (2009). Meningkatkan Kemampuan Berpikir Kreatif Siswa. (Online), (http://www.virtualsalt.com/crebook1.htm), diakses 13 Juli 2010.

Yudi, M., Ariani, N. M., \& Ramadianti, W. (2017). Desain Bahan Ajar Mata Kuliah Aljabar Linear untuk Mengembangkan Kemampuan Berfikir Kreatif Matematis. KALAMATIKA Jurnal Pendidikan Matematika, 2(1), 1-14. 